\title{
Den dansk-amerikanske forbindelse og Karen Blixens debut
}

\author{
I 1934 fik Karen Blixen sin forste bogpå tryk: Seven Gothic Tales. Denne debut var \\ resultatet af en langere proces, hvor ikke mindst venskabet mellem hendes moster, Mary \\ Bess Westenholz, og den amerikanske forfatter Dorothy Canfield Fisher spillede en \\ betydelig rolle.
}

aflektor Allan Røder

$\mathrm{M}$ ary Bess Westenholz var i sin tid et meget aktivt medlem af unitarernes danske menighed og redaktør af deres blad. Derudover virkede hun i en vis udstrækning som forfatter og debattør, men det er nok ikke forkert at sige, at hun i dag er mest kendt i sin rolle som Karen Blixens 'Moster Bess.' I september 1932 skrev hun om sin niece:

"I won't begin enumerating her faults and virtues, I would not know where to end. As she is, she is very very dear to me and my heart bleeds, when I think of her as it bleeds for an eagle in a cage - therefor whatever you could do to help her with her stories, you do for me."

Brevet var en del af korrespondancen mellem den amerikanske forfatter Dorothy Canfield Fisher i Vermont og nogle af de mennesker, der stod Karen Blixen nærmest - en korrespondance, der begyndte med Westenholz' første henvendelse i 1927 efter at have læst en af Dorothy Canfields romaner og sluttede i 1950'erne. Størstedelen af de bevarede breve findes i dag i arkiverne hos University of Vermont og Det Kongelige Bibliotek.

Man fornemmer i brevene, hvor vigtigt det var for Westenholz at portrættere sin niece som en usædvanlig, sammensat og interessant personlighed:

"her faults and virtues, her gifts, her energy, her vanity, her generosity - everything about her is on a much larger scale than ordinary women's, she will make me fret and fume with indignation and compel me to bow my head in deep admiration."

Langtfra noget fejlfrit menneske i mosterens optik. Samtidig er det dog også tydeligt, at Westenholz gjorde rigtig meget ud af at understrege, hvor begavet og talentfuld niecen var. Men der stod også meget på spil. Karen Blixens manuskript - det, der senere skulle blive udgivet som Isak Dinesens Seven Gothic Tales, - var samme sommer blevet sendt til Vermont, og meget afhang nu af, om Canfield fandt en amerikansk forlægger til at udgive det. Thomas Dinesen ville senere fremstille hele processen som ret enkel: han havde sendt søsterens fortællinger til Canfield, som straks havde fåt sin forlægger til at antage dem, og kort efter fulgte udnævnelsen til 'book of the month.' Senere er det blevet påvist, at hele forløbet var meget mere kompliceret, og når Canfield besluttede sig for at komme til undsætning, var det først og fremmest for Westenholz' skyld. 
Som følge af det venskab, der efter få års brevveksling var opstået med hende, kom Canfield til at spille en central rolle i de to søskendes fremstød for at få manuskriptet offentliggjort. Med sine gentagne forsøg på at skabe interesse for værket blev den amerikanske forfatter et vigtigt led i den proces, som til slut førte til, at den hidtil ukendte Dinesen fik sin bogdebut - efter et noget turbulent forløb med flere op- og nedture. ${ }^{3}$

\section{En amerikansk karriere}

Når Canfields egen debut i sin tid havde været mere uproblematisk, skyldtes det, at den amerikanske forlagsverden ved århundredets begyndelse havde været ikke så lidt nemmere at forhandle med end ved begyndelsen af den finansielle krise i 1930'rne. I det første tiår af det tyvende århundrede kom der mange nye kvindelige læsere til i Amerika, og situationen var gunstig for forfattere, som faldt i deres smag, især når man som Canfield allerede fra starten havde flere gode kontakter, der var venner af familien, heriblandt forlæggeren Henry Holt, der udgav de fleste af hendes tidlige bøger, og William Lyon Phelps, som i de følgende årtier blev en af landets mest indflydelsesrige kritikere. ${ }^{4}$

Da hun var i tyverne, giftede hun sig og flyttede til Arlington, Vermont. Hun fik nogle skitser og noveller optaget i tidsskrifter og begyndte for alvor at satse på at blive forfatter. Hendes mand, John Fisher, måtte efter et afbrudt universitetsstudie ved Columbia, hvor han havde delt værelse med Alfred Harcourt, snart opgive sine forfatterdrømme, men da Alfred Harcourt i 1919 efter nogle år i Henry Holts firma grundlagde Harcourt \& Brace, flyttede Canfield med, og han udgav hendes bøger fra da af.
En af hendes første bøger skulle på langt sigt vise sig at blive hendes populæreste, nemlig Understood Betsy, hvor en pige slipper væk fra sit overbeskyttede hjemmeliv og kommer til Vermont, hvor hendes familie giver hende udfordringer og plads til at udvikle sig og lære at klare sig selv. Canfield var på dette tidspunkt meget optaget af Maria Montessoris teorier om børneopdragelse og skrev flere fagbøger for at udsprede kendskabet til hendes metoder; en af dem udkom på dansk i 1919, samme år som Karen Blixen kom til Danmark fra Afrika på et længere besøg og begyndte at interessere sig for dem. ${ }^{6}$

I mellemkrigstiden skrev Canfield de fleste af sine bøger, og her var hendes betydning og indflydelse størst, - dels fordi hendes værker nåede ud i stadig videre kredse, og dels fordi hun fra 1926 var medlem af bedømmelseskomiteen i bogklubben Book-of-the-Month Club. Her tenderede hendes smag i mange tilfælde mod det lidt mere veletablerede og traditionelle. Den moderne, strengt objektive skrivestil var hun f.eks. ikke glad for. Hun kunne lide de klassiske, brede forfatterkommentarer, der gav læseren mulighed for større forståelse og måske også indlevelse og medfølelse, og hun var ingen tilhænger af historier af typen "A man lived in the woods. So did a bear. The man killed the bear."

Men de mere naturalistiske tendenser begyndte efterhånden at gøre sig gældende. Kritikeren H.L. Mencken gik i offensiven mod William Lyon Phelps og andre "Victorians" og slog til lyd for en ny og tidssvarende litteratur, der skulle være mindre bornert og puritansk end den gamle. ${ }^{8}$ De problematiske elementer fandtes, mente man, ikke mindst i de små 
byer og landsbyer; beretninger om de ulykkelige tilstande i udkantsområderne fik vind i sejlene og stod i skarp kontrast til Canfields historier, hvoraf en del handlede om det gode liv i landsbyerne i New England.

Men også af andre årsager kom hun under beskydning i 1920'rne og 1930'rne. For der var blandt de moderne litterater, også blandt andre end Menckens tilhængere, en tendens til at påpege nødvendigheden af at reducere det kvindelige element i amerikansk litteratur, "det kvindelige Aandsherredømme," som det blev kaldt. ${ }^{9}$ Der var udbredt anerkendelse af f.eks. Willa Cather, men derudover mente mange, at kvinder generelt simpelthen havde fået for meget at sige inden for det kulturelle gebet, og at der havde været "en frygtelig Diletantisme af skrivende Damer." ${ }^{10}$ Canfield blev således i disse år kritiseret fra flere sider, men formåede alligevel at fastholde den indflydelse, der gjorde det muligt for hende at række en hjælpende hånd til andre forfattere, som havde brug for det.

Efter den økonomiske krises start i 1929 blev der lidt efter lidt et større marked for historier, der ikke nødvendigvis stræbte efter at afbilde virkeligheden præcis, som den så ud i det moderne amerikanske samfund. Der blev større interesse for historiske romaner, bøger om andre tidsaldre, fjerne lande eller for den sags skyld afsondrede, traditionelle lokalsamfund i Amerikas nordøstlige hjørne. Denne udvikling var medvirkende til, at Canfields historier stadig var i høj kurs; f.eks. kan nævnes, at føljetonrettighederne til hendes roman Bonfire, om en landsby, hvor optimisme og sammenhold sejrer over et truende finansielt kollaps, i 1933 indbragte 30.000 dollars, ${ }^{11}$ - men hjalp også med til, at det på trods af Karen Blixens vanskelige udgangspunkt som ukendt dansker i den amerikanske forlagsverden kunne lykkes at få Seven Gothic Tales udgivet i 1934.

\section{Den dansk-amerikanske forbindelse}

Karen Blixens bogdebut kan siges at være et resultat af Canfields mangeårige forbindelse med Mary Westenholz; en forbindelse, som tog sit udgangspunkt i Westenholz' interesse for Canfields roman fra 1926, Her Son's Wife.

Forholdet imellem de to kvinder viste sig hurtigt at være noget, som begge parter ønskede at bygge videre på, og de havde da også flere ting til fælles, deriblandt deres positive forhold til religion. Trosfæller var de ganske vist ikke: mens Westenholz' tilhørsforhold i inderkredsen af unitarernes menighed betød meget for hendes liv, følte Canfield sig knyttet til kvækernes retning, som både hendes mand og flere af hendes nærmeste venner tilhørte. ${ }^{12}$ Derudover var hun helt igennem villig til at vedkende sig en vis form for puritanisme $-i$ en moderniseret, tidssvarende udgave, neo-puritanisme, med større vægt end tidligere på medmenneskelighed og forståelse. Da en kritiker mente at finde tydelige tegn på denne form for puritanisme i Her Son's Wife, stod hun ved sine holdninger og mente, at han havde forstået romanen fuldkommen, som hun havde tænkt sig det. ${ }^{13}$

Selv var hun altså ikke unitar; men at hun havde en betydelig sympati for unitarer, og at deres overbevisning ikke lå hende så fjernt, får man en klar fornemmelse af, når man læser om familien Crittenden i romanen Rough-Hewn: her møder man et stilfærdigt, sympatisk par, gode og kærlige forældre, som er i stand 
til at give deres barn Neale en god og tryg opvækst. Deres kristne grundholdning har ikke nogen større betydning for familiens liv, heller ikke om søndagen:

"The Crittendens were Unitarians, not much given to church-going anywhere, and the nearest Unitarian church was across the river in New York. Mr. Crittenden had enough of New York on week-days. So they never went." ${ }^{14}$

Men da Neale senere står i et moralsk dilemma, sidder det religiøse alligevel i ham og får ham til at vælge det rette, selvom det er svært:

"Nine generations of Puritan forebears would not let Neale abandon his ideal because it hurt him." ${ }^{15}$

Et andet punkt, hvor Canfield og Westenholz havde fælles interesser, var kvindesagen. Begge håbede på større ligestilling og på en ny generation af kvinder med større gennemslagskraft.

Westenholz var aktiv i Dansk Kvindesamfund, og i sin essaysamling Fra mit Pulterkammer viste hun under pseudonymet Bertel Wrads sin interesse: Wrads slog til lyd for, at kvinder måtte kunne spille en langt større rolle ude i samfundet, uden at det behøvede gå ud over familielivet. Canfield var meget enig med Wrads og var i sine romaner ikke mindst fokuseret på ulighederne på arbejdsmarkedet:

"All her brothers had been allowed to follow the light as God gave them to see it - doctor, lawyer, merchant, chief whatever took their fancy; but when she made up her mind that she wanted to be a woman doctor, her family met in convocation and fell into fits, and told her to get herself a husband and some babies."

Selvom mange af de breve, som Westenholz i tidens løb sendte til Ver- mont, er blevet bevaret, er næsten ingen af Canfields svar blevet fundet indtil videre. Alligevel kan man mange steder - som f.eks. når Westenholz gentog det tilsendte - finde vidnesbyrd om, at deres forhold på få år udviklede sig til et stabilt og velkonsolideret venskab, som begge parter værdsatte:

"'With a heart full of love and thankfulness for having you.' The last words in your delightful letter shall be the first in my answer. - I wonder at myself feeling so young and enthusiastic - falling in love as a little maid of 13 with a grown up lady of 18 , it is simply delightful this renaissance, this jumping of the heart, when I see a letter from you." ${ }^{17}$

I sommeren 1932 kom så det brev til Vermont, hvor Thomas Dinesen først måtte introducere sig og derefter på sin søsters vegne spørge, om der kunne være nogen mulighed for at afsætte de vedlagte fortællinger. Når Thomas Dinesen i Tanne senere skrev, at han inden dette brev havde været sammen med Canfield flere gange og korresponderet en del med hende, var det en overdrivelse. Først flere år senere påbegyndtes en regelmæssig korrespondance imellem dem.

Det betød dog ikke, at de ikke allerede dengang ville kunne finde nogen fælles referencepunkter i deres liv og livssyn. Noget af det, der betød mest i Thomas Dinesens liv, spillede også en stor rolle i Canfields: de havde begge været i Frankrig under krigen og hjulpet til hver på sin måde, Dinesen endda i forreste linje. Neales tapperhed og følelser, som Canfield beskriver dem efter krigen, hvor han mindes kampene i Frankrig med glæde og en vis nostalgi, passer med dem, som Dinesen beskriver i sin erindringsbog $N o$ Man's Land. 
Canfield var under Første Verdenskrig taget til Frankrig med mand og to børn for at deltage i humanitært hjælpearbejde bag fronten. Denne krig, som blandt mange af den yngre generations forfattere var noget af det, der gav den tidligere så udbredte amerikanske optimisme et grundstød, og som også Karen Blixen betegnede som "det mest katastrofale i vor tid," 18 var for Canfield ikke uden mindre lyspunkter, - bl.a. fordi hun formåede at hente trøst i den bibelsk inspirerede tanke, som hun beskrev i sine skitser fra Frankrig: at al den lidelse, som krigen forårsagede, var som veerne ved en fødsel, og at der måske kunne komme noget godt ud af det, nemlig en ny bevidsthed om menneskelig solidaritet på tværs af grænser. Som hun senere udtrykte det $i$ en roman om krigen: "It takes anguish to bring new life to birth." ${ }^{19}$ Derudover bemærkede hun, hvordan mange kvinder, så længe krigen varede og mændene var i felten, fik en sjælden lejlighed til at vise, at de udmærket var i stand til at overtage mænds arbejde, når der var behov for det. ${ }^{20}$

Heller ikke for Thomas Dinesen var krige noget entydigt negativt:

"Rimeligvis vil fremtidens historikere om nogle få slægtled se på vor urolige tids lidelser som ikke stort mere end de beklagelige men uundgåelige smerter, som altid vil være forbundet med fødslen af en ny tidsalder, rigere på alle slags menneskelige værdier end nogen tidligere." ${ }^{21}$

Da han højt dekoreret efter krigen blev genforenet med sin søster, som bla. pga. de kaotiske transportforhold det år kom noget forsinket hjem fra sin problematiske og usikre tilværelse i Afrika, var det stadig med en del optimisme i behold.

Han ville også udmærket kunne sætte sig ind i det, når Mary Bascomb, hoved- personen i Her Son's Wife, i en vanskelig situation nægter at opgive håbet: "She could not let it go. She came of fighting stock. Not one of all the throng of her ancestors had seen any beauty in resignation or submission." ${ }^{22}$ Både slægt og forfædre betød noget for Canfield og kunne også i hendes eget liv være med til at holde modet oppe. Hendes familie havde boet i Arlington siden landsbyens grundlæggelse, og herfra kom inspirationen til mange af hendes historier. Let varierede versioner af, hvordan forfædrene oprindeligt var kommet ridende for at grundlægge det nye hjem, eller hvad bedsteforældre havde oplevet i skovene, indgik i hendes fortællinger. Og i situationer, hvor hendes personer er i tvivl eller problemer, er det ofte deres forfædre, der $i$ en eller anden skikkelse kommer dem til hjælp; forfædrene ligger dem i blodet og gør, at de nemmere finder ud af det. Den person, der fascinerede hende mest, var ubetinget hendes oldemor, Almera, som hun beskrev i flere omgange - en meget selvstændig kvinde, som altid var parat til at kæmpe for sine synspunkter.

Også Thomas Dinesen var optaget af sin slægt og forfædre og mente, at han havde arvet meget fra dem; betydningen af arv og miljø var netop en af de ting, som han og Karen kunne være meget uenige om. ${ }^{23}$ Ligesom Canfield interesserede han sig specielt for sin oldemor og skrev som ældre en dagbogsroman om hende. Dog var denne oldemor en ganske anden type end Canfields: mens Almera Canfield i sin efterkommers skildringer for det meste var barsk og stridslysten, aldrig skænkede sin mand en tanke og kunne være meget vanskelig at have med at gøre, hvis der var noget, der ikke levede op til hendes idealer, var Dinesens 
favorit, Anne Margrethe, først og fremmest en langt mere føjelig og underdanig kvinde, hvis forhold til manden, den modige, succesrige og krigsvante soldat, livet igennem var præget af kærlighed, respekt og beundring.

\section{Manuskriptet}

Canfield fandt det tilsendte manuskript meget anderledes end det, hun var vant til, men spændende. Mens nogle kritikere senere ville studse over Blixens fremstilling af kvinder i mandetøj og manderoller, havde Canfield ikke noget problem med dette. Hun var vokset op sammen med Willa Cather, der livet igennem, lige fra de unge år til hun blev en anerkendt forfatter, havde en forkærlighed for at klæde og opføre sig på en måde, der måtte opfattes som maskulin. Canfields ideal var pionærkvinden, som hverken var sart eller feminin, ikke veg tilbage for nogen farer og kunne påtage sig næsten en hvilken som helst opgave, - noget lignende Cousin Ann, der med sine mandevaner og arbejdstøj bliver et forbillede for hovedpersonen i Understood Betsy og gør sit til, at Betsy udvikler sig til et stærkt og helt menneske. ${ }^{24}$ Canfield var i det hele taget lige fra begyndelsen af positivt indstillet over for det tilsendte materiale.

Da Westenholz i september 1932 havde hørt om Thomas' og Karens brev og forstået, at manuskriptet var blevet sendt, og Karens hele fremtid nu måske stod på spil, tog hun Her Son's Wife ned fra hylden og genlæste et uddrag af historien om den ældre, enlige kvinde, som romanen igennem forsøger at finde ud af, hvordan hun kan leve sammen med de unge i familien og sørge for, at hendes barnebarn Dids får den bedst mulige start på livet og kan udvikle sig til en kvinde med alle muligheder for et godt liv. ${ }^{25}$ I uddraget sker der flere forandringer i Mary Bascombs forhold til sin søn Ralph - et forhold, der i flere henseender kunne minde om Westenholz' til Karen Blixen - og man finder den linje, der sidenhen er blevet det mest almindeligt udbredte Dorothy Canfield-citat: "a mother is not a person to lean upon, but a person to make leaning unnecessary."26

At det i nogle situationer kan være svært for den ældre generation at lade den yngre stå på egne ben illustreres få sider længere henne i samme uddrag, hvor Ralph takket være sin mors gode forhold til den lokale redaktør har fået udskiftet sit hidtidige, uinteressante arbejde med et nyt og spændende job som journalist. Det er en stor chance for ham, men han har aldrig før fået noget på tryk og må arbejde intenst for at lære at skrive, som det nu forventes af ham, så det kan lykkes ham at få sin debut i bladets spalter.

I de samme kapitler findes beskrivelsen af, hvordan det endte med at gå med Dids. Som ganske ung var hun begyndt at komme i dårligt selskab og komme sammen med en mand, der ikke var den rette, men Mary Bascomb havde sørget for, at Dids mødte den kendte, karismatiske Dr. Levering, som imponerede hende. Westenholz beskriver et sted værdien af at lade mennesker, som er på vildveje, møde det, som hun kalder for et overmenneske, et menneske som Dr. Levering - med "ædlere Tanker" og "et varmere, rigere Hjerte", ${ }^{27}$ og efter mødet med ham slog Dids da også ind på en mere lovende bane i livet og frigjorde sig fra sine tvivlsomme bekendtskaber. Takket være den vældige indsats, som Mary Bascomb gennem årene havde gjort for at nå dette mål, lykkedes det til sidst at gøre 


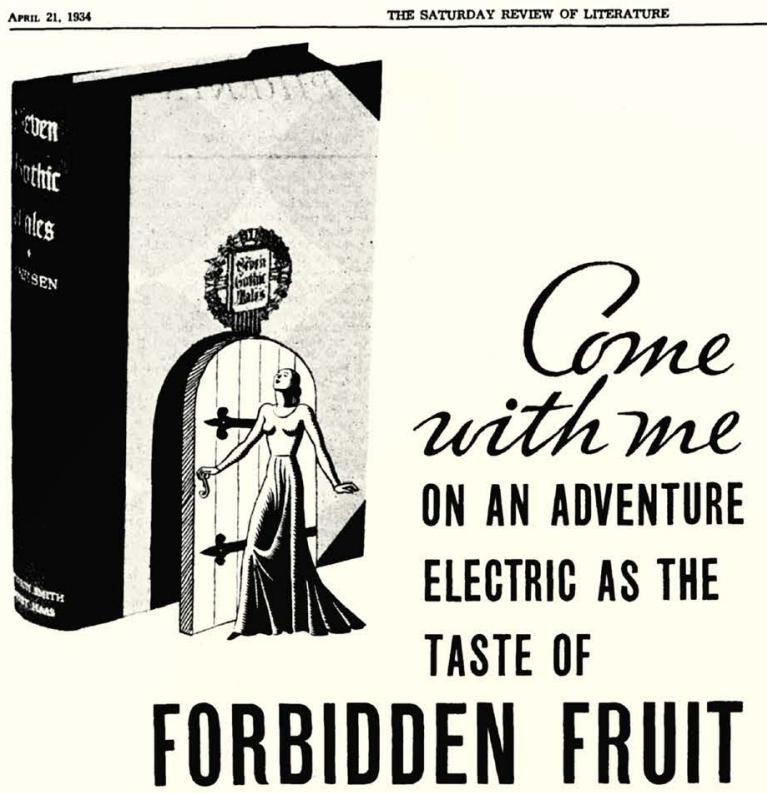

\section{SEVEN GOTHIC TALES}

is compared to the works of these great writers:-

SHAKESPEARE

of Dineerthing of Shakespeare in the yo of Dinesen's imagination, restricting himseri
nerither to one particular arta, nor to one par-
ticular field of pecialization.-W. Y. Sun.

BOCCACCIO

HENRY JAMES

A.. A book bringing the psychological in. Northern Boceaccio ... a creation in foctinn of so astonishing a briliance that far fel like
ranking it a trong the great imagined epiodes posterous praice." -William Rose Benit, Sat.

BALZAC

MAX BEERBOHM

It is essentially a Balzacian world that lak

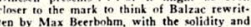
lightrocm.o wilfully entangled you cannot

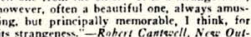

BOCCACCIO

RABELAIS

GOETHE

BYRON

"For the sheer magie of story telling, these
ales stand ousside our century. There is an

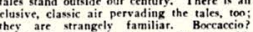

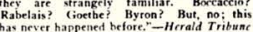
Bnoks

WHAT is this strange and sensuous flavor of Gothic Tales-

so ancient and yet so new, so baffling that excited reviewers have found it indescribable? Some have likened it to white magic and an cerie light. Others have striven manfully to find fresh and illuminating words in which to reveal it - a few have given up in frank despair.

What they have all done, however, is to find in these Gothic Tales a likeness to the great in all the realms of literature-to BOCCACCIO, to ANATOLE: FRANCE, to GOETHE, RABELAIS, BYRON, and many others whose writings bear the stamp of genius.

The meaning of this chorus of praise is unmistakable: that the book is unique, that it encompasses the arts and perceptions of the ages, that Isak Dinesen writes with authentic new genius . . . and that the lost art of story-telling has come back into the world to enthrall you, to amuse you, to lift you to mystic realms of adventure and romance. SEVEN GOTHIC TALFS is your book to savor and enjoy.

Book-of-the-Month Club Selection 420 pages
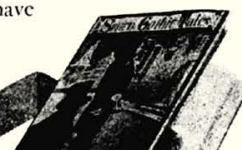

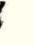

BOCCACCIO

CASTIGLIONE

DE MAUPASSANT

ERNST HOFFMANN

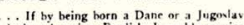

he brilliance of lkak Dinesen's style, I woutld

go about it. ... Where are these pcople? In
ome vaguely defined European and. Some.

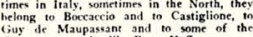
Eeven Gothic Tales excite- me mote than

CERVANTES STEVENSON BYRON

"Byron's moral atmoophere is that of a taive kindly, immature youth compared to the tense.
fierce, hard, controlled, over-civilized, savage anonymous author. Is it of Cervantes? of R. I. Stevenson?
will ask yourself, puzziled, have I I ever en ageously unexpected. sometimes horrifying

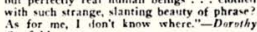

BOCCACCIO ANATOLE FRANCE

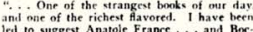
… A book that wil be long remembered."

POE

BAUDELAIRE

. Contains many of the talents of Poe
and Badedainer.

Harrison SMith and Robert HaAs 17 East 49th Street New York

Forlagets reklame for Seven Gothic Tales $i$ The Saturday Review of Literature, 21. april 1934.

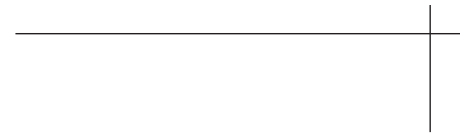


barnebarnet til alt det, hun havde håbet på - succesrig, selvsikker og fornuftig. I en situation, hvor hele niecens fremtid måske stod på spil, - efter mange års hjælp, støtte og åndelig inspiration fra Westenholz' side - læste hun igen om, hvor vellykket resultatet af mange års påvirkning fra den ældre generations side kunne blive.

Det var en hel del sværere at finde nogen til at udgive de fantastiske fortællinger, end det nogle gange har været fremstillet. Og også da Canfield fik gjort den amerikanske forlægger Robert Haas opmærksom på dem, var han først længe utilbøjelig til at antage manuskriptet fra den ukendte, udenlandske forfatter, indtil han pludselig efter nogle måneder ændrede holdning. Hvad der endegyldigt fik ham til at skifte mening i 1933, vil nok aldrig kunne siges med fuldkommen sikkerhed, men man kunne forestille sig, at den første fortælling i det tilsendte manuskript her kan have spillet en rolle.

For en dansk læser kan "Vejene omkring Pisa" i sin helhed måske minde ikke så meget om Émile Zolas roman Rome, som Karen Blixen selv nævner som inspirationskilde, ${ }^{28}$ men snarere om Thomasine Gyllembourgs novelle "Nisida" - en historie, som med sin beretning om en aristokratisk pige, som kommer til at vokse op i borgerligt-kristne omgivelser godt kunne appellere til Karen Blixen. Også her sættes handlingen i gang først i 1800-tallet, da en fornem karet pludselig i meget stærk fart kommer ind på en fredelig scene, hvor en ung mand har siddet i egne tanker, hvorefter han med et slag bliver viklet ind $i$ en historie med erotiske og familiære forviklinger: en ung sydlandsk skønhed er af sin adelige familie blevet tvunget til at gifte sig med en mand med formue og rang, men elskede en anden og måtte nu vælge mellem pligt og tilbøjelighed. Hun valgte det sidste, og som i Karen Blixens fortælling er det også her medvirkende til at sætte gang $\mathrm{i}$ handlingen; $i$ begge historier er der dueller, ægteskaber, der hurtigt bliver kendt ugyldige af den katolske kirke, og unge nygifte kvinder, som dør i barselseng, men når at få en lille pige, Nisida og Rosina, der i syttenårsalderen til sidst i historien - cirka 1822 i begge historier - sidder med en lykkeligt genforenet familie samlet omkring sig.

Men en amerikansk læser, som havde fingeren på pulsen i bøgernes verden, ville i 1933 snart blive opmærksom på Hervey Allens nye roman Anthony Adverse. Canfield og hendes kolleger i Book-of-the-Month Clubs bedømmelseskomité læste og bedømte den det år; her må der have været tale om en vis begejstring, eftersom den endnu uudkomne mammutroman endte med at blive valgt til månedens bog for maj måned. Sceneriet og baggrunden for fortællingen kan minde om "Vejene omkring Pisa," og indledningen først og fremmest: den fornemme karet, der på en rejse på en smuk forårsdag omkring år 1800 i den katolske sydlige del af Europa pludselig i alt for høj fart kommer ind på den fredelige, landlige scene, lige før den dramatiske ulykke. At Haas, som bl.a. via Canfield vidste meget om, hvad der rørte sig i Book-of-the-Month Club, også i dette tilfælde blev holdt underrettet, må anses for temmelig sandsynligt. Canfield og hendes kolleger havde set rigtigt, og Anthony Adverse kom godt fra start: allerede før den blev udgivet i juni, var der mange tusind forhåndsbestillinger, og den endte som en af bogbranchens helt store succeser. ${ }^{29}$ 


\section{Forordet}

Under alle omstændigheder endte Robert Haas med at beslutte sig til at tilbyde Karen Blixen en kontrakt, og de nåede til enighed. Midt i juni skrev Westenholz:

"Now at this moment my sister telephoned, that she had just had a letter from Tanne telling about her telegraphic correspondence with your publisher. It seems to me wonderfully promising, I must just wait and see, what comes out of it, it seems too good to be true." 30

Den underskrevne aftale om udgivelsen af de syv fortællinger blev dateret 23. juni. ${ }^{31}$ Dagen før skrev Canfield fra Arlington:

"Say Bob, I don't want to seem to put myself forward and if you don't want this, you are to say so plainly, but how would it be if I wrote an introduction to the Danish stories of the Baroness Blixen? I'd like very much indeed to, if you think it would give the book a boost. But I don't know about such things, and perhaps nowadays in the publishing world, that wouldn't be of use. Say the word if you'd like it." 32

Umiddelbart herefter rejste Canfield på en tur til Europa. Da hun nogle dage senere ikke havde fået noget svar på sit brev, og R.M.S. "Olympic” nærmede sig Cherbourg, lod hun igen høre fra sig:

"Did I, Bob, or didn't I - those last few days were really rotten hectic and disjointed and I can't remember what I wrote and what I just meant to write write you that I'll be glad, if you think it a good idea, to write an introduction to those Danish tales. I meant to, anyhow, and do now." 33

Hun fik herefter snart grønt lys fra Haas og bad om at få fortællingerne tilsendt. Karen Blixen skrev, at hun på dette tidspunkt ikke selv havde nogen forslag til, hvad forordet skulle indeholde, men overlod det til Canfield, som derefter begyndte på arbejdet.

Canfield indledte sit forord med at vedgå, at der med disse syv fortællinger var tale om noget helt uden for det gængse og tilvante, og hun benyttede billedet med den nye og uprøvede frugt, som man for første gang sætter tænderne $\mathrm{i},-$ "The person who has set his teeth into a kind of fruit new to him, is usually as eager as he is unable to tell you how it tastes $^{\text {"34 }}$ - et billede, som faldt godt i tråd med de bibelske allusioner til paradis og syndefald i fortællingerne og blev benyttet i reklamer for bogen, hvor man kunne læse, at anmeldere havde set ligheder med nogle af verdenslitteraturens største navne - Shakespeare, Balzac, Goethe, Byron, Poe og flere andre - men hvor ordene "forbidden fruit" samtidig var specielt fremhævet og knyttede an til den på dette tidspunkt meget velkendte titel på første del af Anthony Adverse, "The Fruit of the Tree." ${ }^{35}$ Blixen selv var også tilfreds med Canfields indledning og tog mere end tyve år senere billedet op i en lignende anledning: "I remember when I first read Huxley's Chrome Yellow, it was like biting into an unknown and refreshing fruit." ${ }^{36}$

Selvom Canfields egen stil som forfatter var anderledes end den, som hun fandt i de syv fortællinger, kunne hun i dem nemt finde elementer, der vakte genklang hos hende og sagde hende noget. Et af disse elementer var den måde, som musik blev benyttet på. Når en person blev beskrevet som et strengeinstrument, kunne hun genkende det som noget, hun selv havde brugt i sine romaner, og kendte passager fra klassiske musikstykker var for hende - og for hendes personer i roma- 
nerne - ofte den måde, som hun bedst kunne udtrykke følelser på. Canfield citerer Karen Blixens beskrivelse af en smuk efterårsdag i naturen, der slutter: "It was the finale of the symphony," - svarende til afslutningen på beskrivelsen $\mathrm{i}$ en af hendes egne romaner af en tilsvarende smuk, farverig efterårsdag: "It was like the andante of the Kreutzer." ${ }^{37}$ Musikken får i begge tilfælde lov til at afrunde forløbet.

På intet sted i forordet giver Canfield nogen konkrete spor, der kunne afsløre noget om hendes danske forbindelser. Men nogle af de fiktive personer, som hun nævner, kunne godt bidrage til at give læseren en forestilling om dem. Frøken Malin, Anastasia og søstrene fra Helsingør er alle enlige kvinder, som hver især har sit at kæmpe med. De har det ikke nemt og har alle været udsat for skuffelser, fordi de kunne have forventet sig mere af livet. Man genkender dem fra hendes egen fiktion, hvor kvinder af denne type er skildret med indlevelse og forståelse.

Efter at have gjort det klart for Karen Blixens læsere, hvor usædvanlige, velskrevne og fascinerende de syv fortællinger er med deres komplicerede mønstre og mosaikværk, og hvor meget der er at hente i dem, afslutter Canfield sit forord således:

"Perhaps you will allow me, as a Vermonter, to fall back on the New England language of understatement as my final report on these stories, and assure you that in my opinion, it will be worth your while to read them."38

De læsere, som i forvejen kendte til Canfields egne historier og måske netop derfor havde besluttet at ville binde an med det nye, udenlandske værk, hvor hendes var det eneste forfatternavn, der var at holde sig til, ville her nemt kunne blive mindet om hendes kendteste novelle, "The Bedquilt," som er blevet kaldt "a parable of the woman writer, and her creative fantasies." ${ }^{39}$ Denne historie var fra hendes første novellesamling, udspillede sig i ældre tid og handlede om en af Canfields enlige, barnløse kvinder, Mehetabel, hvis liv mest har bestået af skuffelser og modgang, og som nu må bo hos familie. Hendes stilling er vanskelig, men quiltning, som hun har et talent for, bliver hendes chance for at få et meningsfyldt liv. Hun begynder på et ambitiøst, kompliceret mosaikværk, og imod alle odds lykkes det hende efter mange års koncentreret arbejde at fuldføre det $o g$ at få det med på en udstilling, hvor det oven i købet får en særlig udmærkelse. Da hun til allersidst vil prøve at opsummere, hvad det betyder for hende at se sit første store arbejde på en offentlig udstilling, er det umuligt for hende at udtrykke det i ord, og hun ender med at måtte falde tilbage på tidens lokale New England-udtryksmåde, underdrivelsen: "Finally, 'I tell you it looked real good', she assured them and sat staring into the fire, on her tired old face the supreme content of an artist who has realized his ideal." 40

Forordet blev vel modtaget, både hos Haas, Karen Blixen og hendes familie og i en større offentlighed, og fortællingerne selv blev som bekendt en succes i mange lande.

Meget af den transatlantiske korrespondance, der fulgte efter den opsigtsvækkende debut, først med Westenholz, og efter hendes død med Thomas Dinesen, ligger nu i Håndskriftsamlingen. I disse breve spændes der emnemæssigt vidt, lige fra de store linjer og den kolde krig til mere personligt nyt, som når der blev planlagt nye udgivelser, Karen Blixen 
gennemgik helbredskriser, eller Canfields børnebørn kom til Danmark, og oldebørn kom til verden på Sjælland..$^{41}$ Også med baronessen blev kontakten bibeholdt, og Canfield fik regelmæssigt nye bøger sendt til Vermont lige til de allersidste år:

"I shall ask one of my readers aloud (for my eyes are dimming so rapidly, I can no longer read to myself even my most personal letters) to read the 'Last Tales' aloud, as the world moves forward into

\section{Noter}

1 Brev fra Mary Westenholz til Canfield, 27. september 1932, Dorothy Canfield Collection, University of Vermont.

2 Brev fra Mary Westenholz til Canfield, 1. januar 1933, Dorothy Canfield Collection, University of Vermont.

3 Allan Røder: "Dorothy Canfield Fisher Karen Blixens amerikanske forbindelse" i: Magasin fra Det Kongelige Bibliotek, 16:3, 2003, s. 19-34.

4 Mark J. Madigan, red.: Keeping Fires Night and Day. Selected Letters of Dorothy Canfield Fisher, 1993, s. 70, 344, 346. Elizabeth Yates: The Lady from Vermont. Dorothy Canfield Fisher's Life and World, 1971, s. 69.

5 Mark J. Madigan, s. 344.

6 Marianne Juhl, Frans Lasson, Marianne Wirenfeldt Asmussen, udg.: Karen Blixen i Afrika. En brevsamling, 1914-31, bind 1-4, 2013, s. 644 .

7 Dorothy Canfield Fisher: Vermont Tradition. The Biography of an Outlook on Life, 1953, s. 163.

8 H.L. Mencken: A Book of Prefaces, 1920, s. 158.

9 Frederik Schyberg: Moderne amerikansk Litteratur 1900-1930, 1930, s. 13. - Jf. H.L. Mencken, s. 32-33. the darkness of a northern-climate winter which you Dinesens must know as well as Vermonters." ${ }^{42}$

Først med hendes død i november 1958 afsluttedes den lange brevveksling, der var startet forholdsvis upåagtet med Mary Westenholz' henvendelse mere end 30 år tidligere, men som endte med at få afgørende betydning for en af de mest bemærkelsesværdige karrierer i dansk litteraturhistorie.

10 Frederik Schyberg, s. 13.

11 Mark J. Madigan, s. 5.

12 Al Silverman, red.: The Book of the Month. Sixty years of books in American life, 1986, s. 94. - Elizabeth Yates, s. 172-73, 227.

13 Ida H. Washington: Dorothy Canfield Fisher. A Biography, 1982, s. 130-31.

14 Dorothy Canfield: Rough-Hewn, 1922, s. 16.

15 Ibid., s. 106-7.

16 Dorothy Canfield: The Deepening Stream, 1930, s. 26.

17 Brev fra Mary Westenholz til Canfield, 15. januar 1932, Dorothy Canfield Collection, University of Vermont.

18 Else Brundbjerg: Samtaler med Karen Blixen, 2000, s. 259.

19 Dorothy Canfield: Home Fires in France, 1918, s. 75. - Matth. 24,8; Mark. 13,8. Dorothy Canfield: The Deepening Stream, s. 391.

20 Dorothy Canfield Fisher: Our Young Folks, 1943, s. xi. - Jf. Karsten H. Piep: "War as Feminist Utopia in Dorothy Canfield Fisher's Home Fires in France and Gertrude Atherton's The White Morning" i: Women's Studies, 34:2, 2005, s. $165 \mathrm{ff}$. 
21 Thomas Dinesen: Øksen. En legmands livssyn, 1959, s. 17.

22 Dorothy Canfield: Her Son's Wife, 1986, s. 176.

23 Thomas Dinesen: Boganis. Min fader, hans slagt, hans liv og hans tid, 2001, s. 9.

- Thomas Dinesen: Tanne. Min søster Karen Blixen, 2001, s. 115-16.

24 Dorothy Canfield Fisher: Our Young Folks, s. 171. - June Cummins: "Understood Betsy, Understood Nation: Dorothy Canfield Fisher and Willa Cather Queer America" i: Children's Literature, bind 32, 2004, s. 24.

25 Brev fra Mary Westenholz til Canfield, 27. september 1932, Dorothy Canfield Collection, University of Vermont.

26 Dorothy Canfield: Her Son's Wife, s. 262.

27 Bertel Wrads: Fra mit Pulterkammer, 1895, s. 123.

28 Frans Lasson, Tom Engelbrecht, udg.: Karen Blixen i Danmark. Breve 1931-62, bind 1, 1996, s. 567.

29 James D. Hart: The Popular Book: A History of America's Literary Taste, 1950, s. 261-62. - Charles Lee: The Hidden Public. The Story of the Book-of-the-Month Club, 1973, s. 166.

30 Brev fra Mary Westenholz til Canfield, 19. juni 1933, Dorothy Canfield Collection, University of Vermont.
31 Frans Lasson, Tom Engelbrecht, udg.: Karen Blixen i Danmark. Breve 1931-62, bind 1, s. 95 .

32 Brev fra Canfield til Merle og Robert Haas, 22. juni 1933, Dorothy Canfield Collection, University of Vermont

33 Brev fra Canfield til Robert Haas og familie, sidst i juni 1933, Dorothy Canfield Collection, University of Vermont.

34 Isak Dinesen: Seven Gothic Tales, 1934, s. v.

35 Karen Blixen: Syv fantastiske Fortallinger, 2012, s. 685.

36 Else Brundbjerg, s. 210.

37 Isak Dinesen: Seven Gothic Tales, s. ix. Dorothy Canfield: The Bent Twig, 1915, s. 374.

38 Isak Dinesen: Seven Gothic Tales, s. x.

39 Elaine Showalter: "Piecing and Writing," i Nancy K. Miller (red.): The Poetics of Gender, 1986, s. 241.

40 Dorothy Canfield Fisher: "The Bedquilt," i The Bedquilt and Other Stories, 1997, s. 42.

41 Brev fra Canfield til Thomas Dinesen, 20. maj 1958. Det Kongelige Biblioteks Håndskriftsamling.

42 Brev fra Canfield til Karen Blixen, 12. november 1957. Det Kongelige Biblioteks Håndskriftsamling. 